\title{
EFEK FENG SHUI INDEX DI TAHUN MONYET API PADA PASAR SAHAM HONG KONG, TAIWAN, SINGAPURA, DAN INDONESIA
}

\author{
Karina Raesita \\ Prodi Manajemen Fakultas Bisnis dan Ekonomika Universitas Surabaya \\ Email: karinaraesita@gmail.com \\ Putu Anom Mahadwartha \\ Prodi Manajemen Fakultas Bisnis dan Ekonomika Universitas Surabaya \\ Email:anom@staff.ubaya.ac.id \\ Arif Herlambang \\ Prodi Manajemen Fakultas Bisnis dan Ekonomika Universitas Surabaya \\ Email:arif_herlambang@staff.ubaya.ac.id
}

\begin{abstract}
Abstrak
Tujuan penelitian ini adalah menguji reaksi pasar terhadap informasi feng shui index di sekitar tanggal informasi tersebut dipublikasikan dan di sekitar liburan tahun baru imlek di beberapa pasar saham Asia, yaitu Hong Kong, Taiwan, Singapura, dan Indonesia. Dalam penelitian ini, digunakan metodologi event study untuk mengamati abnormal return saham-saham dari sektor yang direkomendasikan feng shui index satu hari sebelum hingga satu hari setelah informasi feng shui index dipublikasikan dan satu hari sebelum hingga satu hari setelah liburan tahun baru imlek. Abnormal return saham-saham dari sektor yang direkomendasikan feng shui index hanya terjadi di Taiwan dan Hong Kong. Namun, tidak ditemukan perbedaan antara abnormal return sektor yang direkomendasikan dan tidak direkomendasikan feng shui index di Hong Kong, sehingga abnormal return yang terjadi di Hong Kong tidak bisa disimpulkan sebagai pengaruh dari informasi feng shui index. Perbedaan antara abnormal return sektor yang direkomendasikan dan tidak direkomendasikan feng shui index hanya terjadi di Taiwan. Karena itu, feng shui index effect hanya terjadi di Taiwan.
\end{abstract}

Kata kunci:

feng shui index, chinese new year effects, event study, abnormal return

\footnotetext{
Abstract

The purpose of the research is to examine market reaction on feng shui idex news, in several Asian market such as Hong Kong, Taiwan, Singapura, and Indonesia. This research uses event study to test the market reaction to feng shui information. This research suggest the abnormal return occured surround the event, specifically $t_{-1}$ and $t_{+1}$ during news announcement; and $t_{-1}$ and $t_{+1}$ during holiday season of Chinese New Year. Feng shui index usually recommended several Industrial sector stock that have best performance during spesific Chinese year. The result showed that abnormal return on recommended stocks only occured in Taiwan and Hongkong. However, in Hongkong market there are no differences of abnormal return between recommended stocks and non-recomended stocks. Therefore this research concluded based on Hongkong result, that the abnormal return occured lesslikely because of feng shui index information. The differences of abnormal return only occured in Taiwan, which showed that Taiwan market affected by Feng Shui index information.

Keywords:

feng shui index, chinese new year effects, event study, abnormal return
} 


\section{Pendahuluan}

Setiap orang yang berinvestasi mengejar imbal hasil atas uang yang telah dikorbankan. Berdasarkan hipotesis pasar efisien Fama (1970) dalam Megginson (1997), strategi trading mengandalkan informasi historis tidak dapat memberikan abnormal return, karena harga saham telah merefleksikan semua informasi historis yang ada. Namun, dengan memanfaatkan pola musiman, seperti holiday effect, investor masih dapat memperoleh abnormal return. Salah satu holiday effect yang paling berpengaruh di negara-negara Asia adalah tahun baru imlek. Tahun baru imlek merupakan festival tradisional terpenting bagi orang Tionghoa (Yuan dan Gupta, 2013).

Penelitian yang ada belum mampu mendeskripsikan faktor yang menyebabkan peningkatan return menjelang liburan tahun baru imlek. Salah satu faktor yang mungkin mempengaruhi peningkatan return di sekitar tahun baru imlek adalah faktor budaya. Brown et al. (2002) menemukan pengaruh kebudayaan Tiongkok, yaitu feng shui, terhadap keputusan investor Hong Kong dan Taiwan untuk berinvestasi di pasar saham, khususnya pada festival-festival penting dalam penanggalan Tiongkok. Feng shui telah menjadi sebuah budaya bagi masyarakat Tionghoa, dan seringkali dijadikan acuan dalam pembuatan keputusan, mulai dari keputusan di bidang arsitektur hingga keputusan investasi di pasar saham. Credit Lyonnais Securities Asia (CLSA), salah satu research-driven broker ternama di Asia, kini tidak hanya menyajikan riset investasi dengan prinsip-prinsip ekonomi, tetapi juga riset investasi dengan prinsipprinsip feng shui. Feng shui index yang dibuat oleh CLSA selalu dihubungkan dengan shio tiap tahun disertai dengan 
unsurnya. Sebelum tahun baru imlek, berbagai lembaga dan ahli feng shui perseorangan mengeluarkan prediksi sektor-sektor yang memiliki kinerja baik sepanjang tahun imlek tersebut, dihubungkan dengan unsur yang dimiliki tahun imlek dengan unsur yang dimiliki setiap sektor bisnis. Meskipun tidak ada penjelasan berbasis ekonomi terkait keakuratan feng shui index, feng shui index tetap diperhitungkan sebagai informasi yang mampu mempengaruhi perilaku investor Asia dalam transaksi saham, dan akhirnya dapat mempengaruhi return saham sektoral secara keseluruhan. Karena itu, penelitian terkait feng shui index sebagai informasi yang menjadi pertimbangan investor dalam pembuatan keputusan investasi dan mampu menyebabkan peningkatan return pada tanggal-tanggal di sekitar liburan tahun baru imlek menjadi topik yang menarik. Yuan dan Gupta (2013) menemukan pengaruh signifikan positif variabel preChinese Lunar New Year (pre-CLNY) terhadap return di Tiongkok, Hong Kong, Jepang, Malaysia, Singapura, Korea Selatan, dan Taiwan. Penelitian juga menemukan pengaruh signifikan positif variabel post-CLNY terhadap return di pasar saham Malaysia saja, dan tidak ditemukan pengaruh signifikan pada return saham di objek lain. Untuk membuktikan keberadaan anomali pasar, penelitian dilanjutkan dengan menguji risiko kondisional di setiap objek. Ketika high return yang diuji sebelumnya ternyata diikuti dengan risiko kondisional yang juga tinggi, high return menjelang tahun baru imlek ini tidak dapat disebut sebagai anomali pasar. Akhirnya, disimpulkan tingginya return menjelang tahun baru imlek di Hong Kong, Jepang, Malaysia, Singapura, dan Korea Selatan tidak disertai dengan tingginya risiko kondisional, sehingga tingginya return 
menjelang tahun baru imlek murni disebut anomali pasar. Namun, tingginya return saham menjelang tahun baru imlek di Tiongkok diikuti oleh tingginya risiko kondisional. Sebaliknya, ditemukan anomali di pasar saham Taiwan. Tingginya return saham menjelang tahun baru imlek di Taiwan justru diikuti oleh penurunan risiko kondisional. Efek tahun baru imlek itu sendiri yang menjelaskan peningkatan return di pasar saham Hong Kong, Jepang, Malaysia, Singapura, Korea Selatan, dan Taiwan.

Brown et al. (2002) menguji pengaruh faktor budaya pada price clustering di pasar saham Asia Pasifik, yaitu Australia, Hong Kong, Filipina, Singapura, dan Taiwan. Menurut feng shui dan kepercayaan Tiongkok, beberapa angka dianggap tidak beruntung dan harus dihindari. Angka empat sangat dihindari oleh orang Tiongkok karena angka empat memiliki pelafalan yang sama dengan mati dalam bahasa kanton. Brown et al. (2002) menduga kecenderungan harga saham untuk berkerumun (clustering) di angka delapan dari pada angka empat di sekitar festival kebudayaan penting dalam penanggalan Tiongkok. Pengaruh budaya Tiongkok terhadap price clustering hanya terjadi di Hong Kong dan Taiwan.

Penelitian ini menggunakan objek badan usaha yang mengandung unsur yang dirkeomendasikan feng shui index dan yang tidak direkomendasikan feng shui index yang terdaftar di beberapa bursa efek di Asia, yaitu Hong Kong Stock Exchange, Taiwan Stock Exchange, Singapore Exchange, dan Bursa Efek Indonesia pada periode 2016.

Berikut adalah permasalahan yang dibahas dalam penelitian ini.

1. Apakah terdapat abnormal return pada sektor yang direkomendasikan feng shui index setelah feng shui index pada 
saat informasi feng shui index dirilis ke publik?

2. Apakah terdapat abnormal return pada sektor yang direkomendasikan feng shui index setelah feng shui index pada satu hari sebelum informasi feng shui index dirilis ke publik?

3. Apakah terdapat abnormal return pada sektor yang direkomendasikan feng shui index pada satu hari setelah informasi feng shui index dirilis ke publik?

4. Apakah terdapat perbedaan abnormal return pada sektor yang direkomendasikan feng shui index antara satu hari sebelum dan satu hari setelah informasi feng shui index dirilis ke publik?

5. Apakah terdapat abnormal return pada sektor yang direkomendasikan feng shui index pada satu hari sebelum liburan tahun baru imlek?
6. Apakah terdapat abnormal return pada sektor yang direkomendasikan feng shui index pada satu hari setelah liburan tahun baru imlek?

7. Apakah terdapat perbedaan abnormal return pada sektor yang direkomendasikan feng shui index pada satu hari sebelum dan satu hari setelah liburan tahun baru imlek?

8. Apakah terdapat perbedaan abnormal return pada sektor yang direkomendasikan feng shui index dan sektor yang tidak direkomendasikan feng shui index pada satu hari setelah liburan tahun baru imlek?

\section{Tinjauan Teori dan Pengembangan Hipotesis}

Jogiyanto (2000) mendefinisikan event study sebagai studi yang mempelajari reaksi pasar terhadap suatu peristiwa yang informasinya dipublikasikan sebagai suatu pengumuman. Karena itu, tujuan event study adalah untuk menguji reaksi 
pasar pada periode waktu observasi pada harga sekuritas seputar waktu terjadinya peristiwa (Peterson, 1989). Kegunaan event study adalah memberikan rasionalitas di dalam pasar, bahwa efek suatu peristiwa akan segera terefleksi pada harga sekuritas di pasar modal. Peristiwa yang dapat diterapkan untuk sebuah event study bisa berupa peristiwa ekonomi maupun non-ekonomi, seperti peristiwa politik. MacKinlay (1997) merumuskan langkah-langkah melakukan analisis event study sebagai berikut:

1. Mendefinisikan event yang diteliti serta menentukan event window

2. Menetapkan kriteria seleksi perusahaan yang diteliti

3. Menghitung normal dan abnormal return harga sekuritas dalam sampel

4. Mengestimasi parameter model menggunakan data-data dalam periode estimasi
5. Melakukan uji hipotesis

6. Mempresentasikan hasil penelitian dan diagnosa

7. Menginterpretasikan hasil dan membuat kesimpulan penelitian Sistem penanggalan hsia diawali pada tahun 2696 SM, yaitu pada masa Dinasti Xia/Hsia, dan dikembangkan di masa Dinasti Shang dan Chou. Sistem penanggalan ini diciptakan pada masa Dinasti $H$ sia, sehingga diberi nama Hsia calendar. Penanggalan Hsia mengikuti sistem penanggalan bulan-matahari (lunisolar calendar) yang didasarkan pada bulan dan matahari. Terdapat 10 batang langit (tiangan / 天干) dan 12 cabang bumi (dizhi / 地支) yang mewakili tiap tahun imlek. Setiap batang langit maupun cabang bumi ini memiliki elemen masing-masing dan polaritas yinyang. 
Tabel 1.

Sepuluh Batang Langit, Yinyang, 5 Unsur

\begin{tabular}{|c|c|c|}
\hline $\begin{array}{l}\text { Tiangan } \\
\text { (天干) }\end{array}$ & 5 Unsur & Polaritas \\
\hline Jia 甲 & Kayu & Yang \\
\hline $\mathrm{Yi} 乙$ & Kayu & Yin \\
\hline Bing 丙 & Api & Yang \\
\hline Dīng 丁 & Api & Yin \\
\hline$\overline{W u}$ 戊 & Tanah & Yang \\
\hline Ji 己 & Tanah & Yin \\
\hline Geng 庚 & Logam & Yang \\
\hline Xin 辛 & Logam & Yin \\
\hline Ren 壬 & Air & Yang \\
\hline Gui 癸 & Air & Yin \\
\hline
\end{tabular}

(Sumber: Gunawan, Hng, Lim, Seah, dan Wong)

Sepuluh batang langit ini mencerminkan 5 unsur dan polaritas masingmasing tiangan. Sepuluh batang langit ini mewakili tiap tahun imlek, sehingga 1 tahun imlek memiliki 1 tiangan, dan akan terus berganti setiap perubahan tahun imlek.
Tabel 2.

Dua Belas Cabang Bumi, Yinyang, 5 Unsur

\begin{tabular}{|c|c|c|c|}
\hline \multicolumn{2}{|c|}{ Dizhi(地支) } & \multirow{2}{*}{$\begin{array}{c}5 \\
\text { Unsur } \\
\text { Air }\end{array}$} & \multirow{2}{*}{$\begin{array}{l}\text { Polar- } \\
\text { itas } \\
\text { Yang }\end{array}$} \\
\hline $\mathrm{Zi}$ 子 & Tikus & & \\
\hline Chou 丑 & Kerbau & Tanah & Yin \\
\hline Yin 寅 & Macan & Kayu & Yang \\
\hline Mao 卯 & Kelinci & Kayu & Yin \\
\hline Chen 辰 & Naga & Tanah & Yang \\
\hline Si 巳 & Ular & Api & Yin \\
\hline $\mathrm{Wu}$ 午 & Kuda & Api & Yang \\
\hline Wei 未 & Kambing & Tanah & Yin \\
\hline Shen 申 & Monyet & Logam & Yang \\
\hline You 西 & Ayam & Logam & Yin \\
\hline $\mathrm{Xu}$ 戌 & Anjing & Tanah & Yang \\
\hline Hai 亥 & Babi & Air & Yin \\
\hline
\end{tabular}

(Sumber: Gunawan, Hng, Lim, Seah, dan Wong)

Sepuluh cabang bumi ini juga mencerminkan 5 unsur dan polaritas masing-masing dizhi. Dua belas cabang bumi ini mewakili tiap tahun imlek, sehingga 1 tahun imlek memiliki 1 dizhi, dan akan terus berganti setiap perubahan 
tahun imlek. Dizhi lebih dikenal sebagai ke-12 shio, yang mewakili tahun kelahiran pada tahun imlek tertentu.

Selain siklus 12 tahunan atau capjie shio yang digunakan untuk menghitung/mencacah tahun berdasarkan peredaran bulan, terdapat juga siklus $60-$ an (sexagenary cycle) yang digunakan untuk mencacah tahun, bulan, hari, dan jam berdasarkan peredaran matahari. Setiap 60 tahun, 60 bulan, 60 hari, atau 60 jam pencacahan dimulai kembali dari awal. Uniknya hitungan tidak dinyatakan dengan menggunakan angka melainkan dengan memakai 60 buah pasangan huruf mandarin seperti diperlihatkan dalam Tabel 3. Pencacahan dimulai dari Jiazi kemudian Yichou dan seterusnya sampai Guihai. Setelah itu pencacahan akan dimulai kembali dari Jiazi. Tabel ini sesungguhnya dibangun berdasarkan 2 set atau himpunan huruf-huruf yang disebut 10 Tiangan ( 天干) atau 10 Batang Langit dan 12 Dizhi (地支) atau 12 Cabang Bumi yang dipasangkan secara berurutan. Karena huruf mandarin biasanya dituliskan dari atas kebawah seperti membentuk sebuah pilar (kolom) maka sepasang huruf tadi disebut Pilar. Elemen atau unsur dan polaritas tiap tahun imlek dilihat dari elemen dan unsur Tiangan pada tahun itu. Sementara itu, shio tiap tahun imlek dilihat dari Dizhi tahun tersebut. 
Tabel 3.

Sexagenary Cycle

\begin{tabular}{|c|c|c|c|}
\hline 1.jia-zi & 16.ji-mao & 31.jia-wu & 46.ji-you \\
\hline 2.yi-chou & 17.geng-chen & 32.yi-wei & 47.geng-xu \\
\hline 3.bing-yin & 18.xin-si & 33.bing-shen & 48.xin-hai \\
\hline 4.ding-mao & 19.ren-wu & 34.ding-you & 49.ren-zi \\
\hline 5.wu-chen & 20.gui-wei & 35.wu-xu & 50.gui-chou \\
\hline 6. ji-si & 21.jia-shen & 36.ji-hai & 51.jia-yin \\
\hline 7.geng-wu & 22.yi-you & 37.geng-zi & 52.yi-mao \\
\hline 8.xin-wei & 23.bing-xu & 38.xin-chou & 53.bing-chen \\
\hline 9.ren-shen & 24.ding-hai & 39.ren-yin & 54.ding-si \\
\hline 10.gui-you & 25.wu-zi & 40.gui-mao & 55.wu-wu \\
\hline 11.jia-xu & 26.ji-chou & 41.jia-chen & 56.ji-wei \\
\hline 12.yi-hai & 27.geng-yin & 42.yi-si & 57.geng-shen \\
\hline 13.bing-zi & 28.xin-mao & 43.bing-wu & 58.xin-you \\
\hline 14.ding-chou & 29.ren-chen & 44.ding-wei & 59.ren-xu \\
\hline 15.wu-yin & 30.gui-si & 45.wu-shen & 60.gui-hai \\
\hline
\end{tabular}

(Sumber: Gunawan, Hng, Lim, Seah, dan Wong)

Cara mengetahui Dizhi tahun tertentu adalah dengan menggunakan rumus:

Number $=($ Year-3)/12.
Sementara itu, cara mengetahui Tiangan tahun tertentu adalah dengan menggunakan rumus:

Number $=($ Year-3)/10 
Tahun 2016 ini merupakan tahun monyet api (Bingshen / 肉).

Cara perhitungannya adalah sebagai berikut:

$$
\text { Dizhi }=(2016-3) / 12=167 \frac{9}{12} . \text { Pembilang }
$$

dari hasil perhitungan ini adalah 9, karena itu dizhi tahun ini adalah dizhi ke-9, yaitu

Shen 申 atau monyet. Tiangan $=(2016-$

$$
3) / 10=2010 \frac{3}{10} \text {. Pembilang dari hasil }
$$$$
\text { perhitungan ini adalah 3, karena itu }
$$

tiangan tahun ini adalah tiangan ke-3,

yaitu Bing 丙 atau elemen api dengan

polaritas yang. Karena itu, tahun 2016

adalah tahun monyet api dengan polaritas

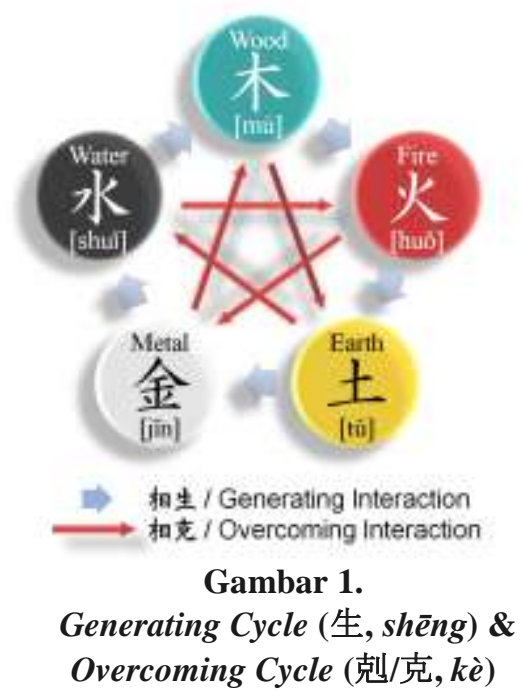

1. Siklus generating (生, shēng)

Dalam siklus ini, kayu menghasilkan api, api menciptakan tanah (abu), tanah memendam logam, logam memperkaya air lewat mineral yang terkandung di dalamnya, dan air memelihara kayu (pohon).

2. Siklus overcoming (剋/克, kè)

Dalam siklus ini, kayu (akar pohon) mematahkan tanah, tanah menyerap air, air menjinakkan api, api melelehkan logam, logam memotong kayu.

Setiap sektor bisnis dapat dikaitkan dengan masing-masing elemen dalam feng shui (tabel 4). 
Tabel 4.

Elemen feng shui dalam tiap sektor bisnis

\begin{tabular}{|l|l|}
\hline Elemen & $\begin{array}{l}\text { Sektor bisnis dan profesi } \\
\text { Logam }\end{array}$ \\
& $\begin{array}{l}\text { Finansial, bank, asuransi, emas, mesin, pertambangan, automobile, } \\
\text { kembuat kunci; hardware; kaca, akuntansi, auditor, militer dan } \\
\text { logam dan kecuangan. }\end{array}$ \\
\hline Kayu & $\begin{array}{l}\text { Profesi terkait penulis, bisnis terkait edukasi, penerbit, bisnis terkait } \\
\text { tanaman, pabrik kertas, pabrik kayu dan furniture, pabrik tekstil, pabrik } \\
\text { alat tulis, produk kesehatan, rumah sakit }\end{array}$ \\
\hline Air & $\begin{array}{l}\text { Bisnis terkait travelling, marine, bisnis minuman, transportasi, pelabuhan, } \\
\text { casino, bisnis pengecer, industri hiburan, segala bisnis terkait air; } \\
\text { penjualan; dan hiburan } \\
\text { panah }\end{array}$ \\
\hline Api & $\begin{array}{l}\text { Psikolog, bisnis terkait kesenian, desain grafis, industri terkait komputer } \\
\text { dan elektronik dan kecantikan, pabrik plastik, restoran dan industri }\end{array}$ \\
\hline
\end{tabular}

(Sumber: Malaysian Institute of Geomacy Sciences, feng shui master Singapore. Sg, diolah)

\section{Credit Lyonnais Securities Asia}

(CLSA) adalah salah satu research-driven

broker ternama di Asia yang menyajikan riset investasi dengan prinsip-prinsip feng shui.

Setiap tahun, CLSA mengeluarkan prediksi pergerakan sektor-sektor saham 
Efek Feng Shui Index ... (Karina Raesita, Putu Anom, dan Arif Herlambang)

yang dibagi berdasarkan 5 elemen dasar

(tabel 5). Sektor yang baik menurut CLSA adalah sektor-sektor yang mengandung unsur logam, yaitu sektor logam (emas dan perak), sektor automobile, sektor permesinan, dan sektor finansial. Sementara itu, sektor yang akan memiliki performa kurang baik adalah sektor api, kayu, dan air. Prediksi CLSA ini didasarkan pada siklus generating dan overcoming (gambar 1).

Tabel 5.

Prediksi Performa Setiap Sektor

Sektor yang bagus

(Sumber: http://clsa.com/special/fsi/2016, diolah) 


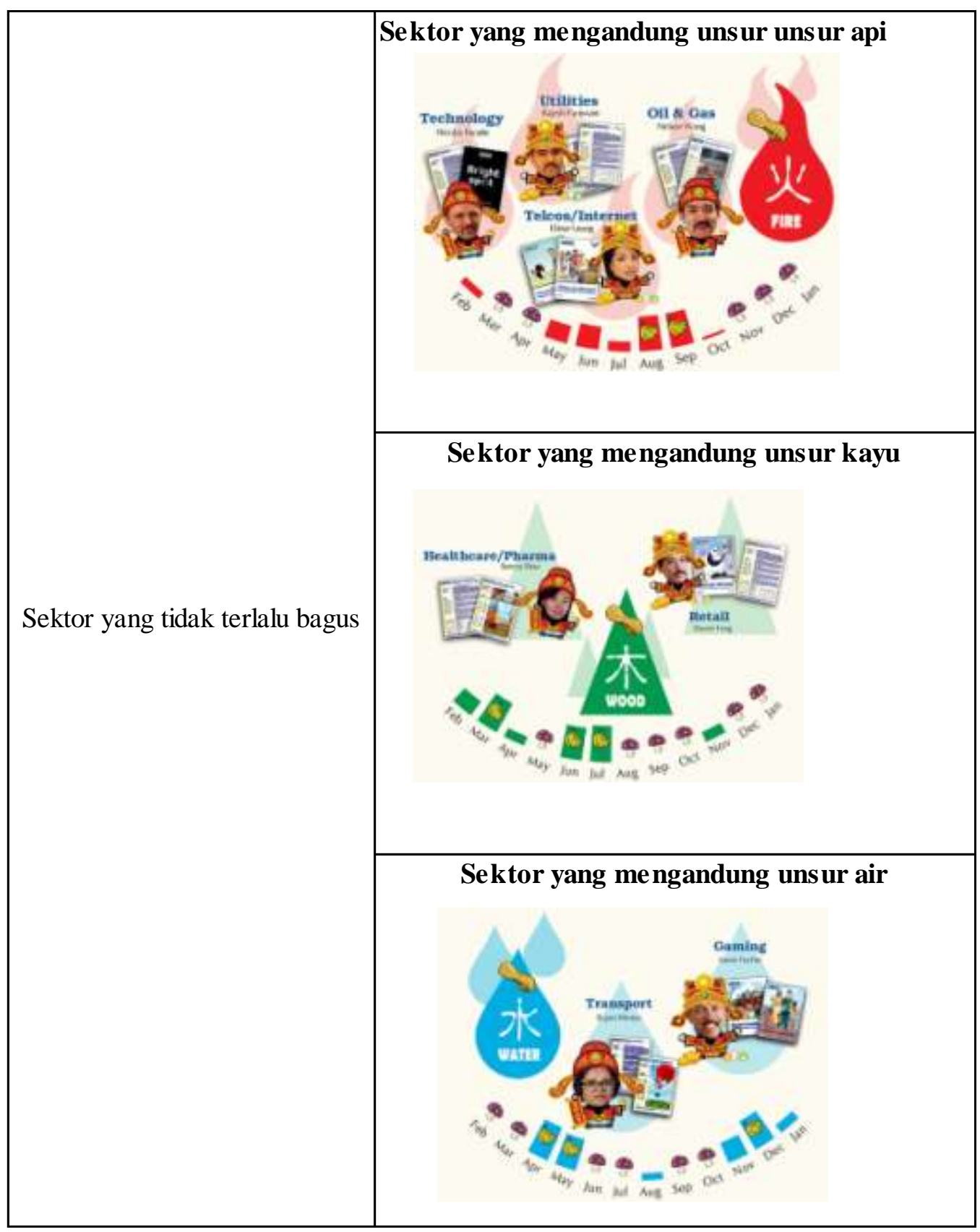

Sumber: http://clsa.com/special/fsi/2016, diolah) 
Efek Feng Shui Index ... (Karina Raesita, Putu Anom, dan Arif Herlambang)

\section{Metode Riset}

Penelitian ini merupakan penelitian konklusif deskriptif dengan pendekatan kuantitatif karena penelitian ini memberikan kesimpulan dari hipotesis yang ada dengan tujuan menggambarkan fenomena abnormal return pasar saham Asia di sekitar tahun baru imlek untuk sektor-sektor yang direkomendasikan dan tidak direkomendasikan feng shui index.

Penelitian ini menggunakan satu variabel, yaitu abnormal return yang merupakan selisih antara actual return dan expected return saham-saham sektor yang direkomendasikan dan tidak direkomendasikan feng shui index.

$A R_{i t}=R_{i t}-E\left(R_{i t}\right)$

Keterangan:

$A R_{i t}=$ abnormal rate of return saham $\mathrm{i}$ pada hari ke $\mathrm{t}$

$R_{i t}=$ rate of return saham i pada hari ke $\mathrm{t}$

$\mathrm{E}\left(\mathrm{R}_{\mathrm{it}}\right)=$ expected return saham $\mathrm{i}$ pada periode estimasi ke $\mathrm{t}$
Sampel penelitian ini adalah saham dari sektor yang diuraikan pada tabel 6 yang telah terdaftar di Hong Kong Stock Exchange (HKEX), Taiwan Stock Exchange (TWSE), Singapore Exchange (SGX), dan Bursa Efek Indonesia (BEI) pada periode estimasi dan tidak mengalami suspend selama periode estimasi. Bursa saham tersebut dipilih mewakili bursa saham Asia.

Tabel 6.

Daftar Sektor yang Menjadi Objek Penelitian

\begin{tabular}{|l|l|}
\hline Sektor yang me- & Sektor yang me- \\
mliki unsur logam & miliki unsur kayu \\
(Jīn / 金) & (Mù / 木) \\
\hline Pertambangan & Industri kertas \\
\hline Industri otomotif & Industri produk hasil \\
\hline hutan \\
\hline Perbankan & Industri farmasi \\
\hline
\end{tabular}

Periode penelitian ini dibagi menjadi

2 yaitu periode estimasi dan event window (gambar 2). Periode estimasi yang digunakan dalam penelitian ini selama 1 tahun untuk mengetahui rata-rata return harian yang akan 
dibandingkan dengan rata-rata return selama event window. Event yang diteliti adalah event saat feng shui index dipublikasikan (t0) dan event tahun baru imlek (T0). Event window dalam penelitian ini yaitu 1 hari sebelum dan 1 hari sesudah informasi feng shui index dirilis ke publik pada 28 Januari 2016 (t0), dan 1 hari kerja sebelum dan 1 hari kerja sesudah liburan tahun baru imlek (T0). Satu hari kerja sebelum liburan tahun baru imlek (T-1) jatuh pada tanggal 5 Februari 2016 untuk HKEX, SGX, dan BEI. Namun, satu hari kerja sebelum liburan tahun baru imlek untuk TWSE jatuh pada 3 Februari 2016, karena pasar saham Taiwan libur pada tanggal 4-7 Februari 2016. Sementara itu, satu hari kerja setelah liburan tahun baru imlek untuk tiap pasar saham berbeda-beda, karena lama libur tahun baru imlek juga berbeda untuk tiap negara.

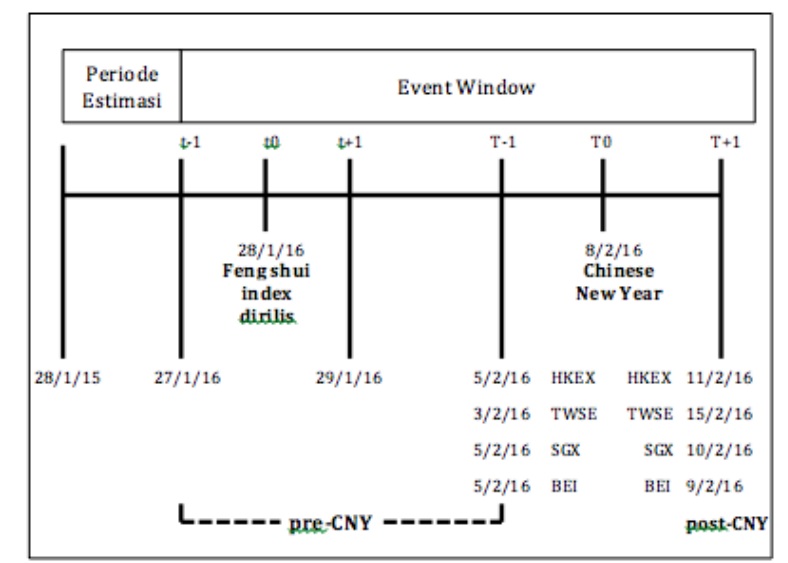

Gambar 2.

Periode Waktu Penelitian

Langkah-langkah yang diperlukan untuk memperoleh abnormal return adalah:

1. Menghitung actual return masing-masing saham badan usaha yang dijadikan sampel secara harian selama periode event window dengan rumus:

$R_{i t}=\frac{P_{i t}-P_{i t-1}}{P_{i t-1}}$

Keterangan:

$\mathrm{R}_{\mathrm{it}}=$ actual return saham i pada hari ke-t $\mathrm{P}_{\mathrm{it}}=$ harga saham penurupan saham i pada hari ke $\mathrm{t}$

$\mathrm{P}_{\mathrm{it}-1}=$ harga saham penurupan saham $\mathrm{i}$ pada hari ke t-1 
Efek Feng Shui Index ... (Karina Raesita, Putu Anom, dan Arif Herlambang)

2. Menghitung market return yang diperoleh dari perhitungan tingkat Hang Seng Index (HSI) untuk Hong Kong Stock Exchange, dan Taiwan Stock Exchange Capitalization Weighted Stock Index (TAIEX) untuk Taiwan Stock Exchange, FTSE ST All-Share Index (FSTAS) untuk Singapore Stock Exchange, Indeks Harga Saham Gabungan (IHSG) untuk Bursa Efek Indonesia. Perhitungan tingkat hasil pasar harian adalah sebagai berikut:

$R_{m t}=\frac{I_{t}-I_{t-1}}{I_{t-1}}$

Keterangan:

$\mathrm{R}_{\mathrm{mt}}=$ return pasar saham pada hari ke-t

$\mathrm{I}_{\mathrm{t}}=$ indeks pasar saham pada hari ke $\mathrm{t}$

$\mathrm{I}_{\mathrm{t}-1}=$ indeks pasar saham pada hari ke $\mathrm{t}-1$

3. Menghitung expected return dengan menggunakan Single Index Market Model (SIMM)

$E\left(R_{i t}\right)=\alpha_{i}+\beta_{i} R_{m t}$

Keterangan:

$\mathrm{E}\left(\mathrm{R}_{\mathrm{it}}\right)=$ expected return saham $\mathrm{i}$ pada periode estimasi ke-t $\alpha_{i}=$ nilai ekspektasi dari return saham yang independen terhadap return pasar $\beta_{i}=$ koefisien yang mengukur perubahan return saham i akibat perubahan return pasar $R_{m t}=$ rate of return pasar pada hari ke $\mathrm{t}$

4. Menghitung abnormal return masingmasing saham badan usaha yang dijadikan sampel secara harian selama event window dengan rumus:

$A R_{i t}=R_{i t}-E\left(R_{i t}\right)$

Keterangan:

$A R_{i t}=$ abnormal rate of return saham $\mathrm{i}$ pada hari ke $\mathrm{t}$

$R_{i t_{i}}=$ rate of return saham $\mathrm{i}$ pada hari ke $\mathrm{t}$ $\mathrm{E}\left(\mathrm{R}_{\mathrm{it}}\right)=$ expected return saham $\mathrm{i}$ pada periode estimasi ke $\mathrm{t}$

5. Mengelompokkan abnormal return saham sektor yang mengandung unsur logam dan sektor yang mengandung unsur kayu selama event window 
IV. Pembahasan

1. Hong Kong

Tabel 7.

Ringkasan Hasil One Sample T-Test pada Sektor dengan Unsur Logam di HKEX

\begin{tabular}{|c|c|c|c|c|}
\hline Tanggal & & & Mean & t-stat \\
\hline 27/1/16 & $\mathrm{t}-1$ & T-8 & $\begin{array}{l}- \\
0.01084 \\
7\end{array}$ & $-3.49 * * *$ \\
\hline 28/1/16 & t0 & T-7 & $\begin{array}{l}- \\
0.01578 \\
5\end{array}$ & $\begin{array}{l}- \\
2.673 * * \\
*\end{array}$ \\
\hline 29/1/16 & $\begin{array}{l}\mathrm{t}+ \\
1\end{array}$ & Т-6 & $\begin{array}{l}- \\
0.06129 \\
5\end{array}$ & $-2.368 * *$ \\
\hline $1 / 2 / 16$ & $\begin{array}{l}\mathrm{t}+ \\
2\end{array}$ & T-5 & $\begin{array}{l}- \\
0.00743 \\
0\end{array}$ & $-2.143 * *$ \\
\hline $2 / 2 / 16$ & $\begin{array}{l}t+ \\
3\end{array}$ & T-4 & $\begin{array}{l}0.00710 \\
2\end{array}$ & $2.297 * *$ \\
\hline $3 / 2 / 16$ & $\begin{array}{l}t+ \\
4\end{array}$ & T-3 & 0.01474 & $\begin{array}{l}4.031 * * \\
*\end{array}$ \\
\hline $4 / 2 / 16$ & $\begin{array}{l}t+ \\
5\end{array}$ & $\mathrm{~T}-2$ & $\begin{array}{l}0.00576 \\
1\end{array}$ & 0.929 \\
\hline
\end{tabular}

\begin{tabular}{|l|l|l|l|l|}
\hline $5 / 2 / 16$ & 6 & & 5 & $2.096^{* *}$ \\
\hline & $\mathrm{t}+$ & $\mathrm{T}+$ & 0.02545 & \\
$11 / 2 / 16$ & 7 & 1 & 8 & $5.24 * * *$ \\
\hline
\end{tabular}

Keterangan:

**: signifikan $5 \%$

***: signifikan $1 \%$

Hasil pengujian one sample t-test pada tabel 7 menunjukkan Hong Kong bereaksi pada $\mathrm{t}-1, \mathrm{t} 0, \mathrm{t}+1, \mathrm{~T}-1$, dan $\mathrm{T}+1$, ditandai dengan terdapat abnormal return pada saham-saham sektor yang direkomendasikan feng shui index.

Tabel 8.

Hasil Uji Perbedaan Abnormal Return Sektor yang Mengandung Unsur Logam pada $t-1$ dan $t+1$ di HKEX

\begin{tabular}{|l|l|l|l|}
\hline Mean & Mean & Mean & \\
$\mathrm{AR}_{\mathrm{t}-1}$ & $\mathrm{AR}_{\mathrm{t}+1}$ & differenc & \\
& & $\mathrm{e}$ & $\mathrm{t}$ \\
\hline- & -0.06130 & & \\
0.01085 & & 0.050448 & 1.935 \\
\hline
\end{tabular}

Berdasarkan hasil uji beda, tidak terdapat beda antara abnormal return saham sektor yang direkomendasikan 
Efek Feng Shui Index ... (Karina Raesita, Putu Anom, dan Arif Herlambang)

feng shui index pada satu hari sebelum informasi feng shui index dirilis dan satu hari setelah informasi feng shui index dirilis.

Tabel 9.

Hasil Uji Perbedaan Abnormal Return Sektor yang Mengandung Unsur Logam pada $\mathbf{T}-1$ dan $T+1$ di HKEX

\begin{tabular}{|l|l|l|l|}
\hline Mean & Mean & Mean & \\
$\mathrm{AR}_{\mathrm{T}-1}$ & $\mathrm{AR}_{\mathrm{T}+1}$ & differenc & \\
& & $\mathrm{e}$ & $\mathrm{t}$ \\
\hline 0.0085 & 0.0254 & - & - \\
\hline & 6 & 0.016913 & $2.667 * * *$ \\
\hline
\end{tabular}

Keterangan:

***: signifikan $1 \%$

Berdasarkan hasil uji beda, terdapat perbedaan antara abnormal return saham sektor yang direkomendasikan feng shui index pada satu hari kerja sebelum liburan tahun baru imlek dan satu hari kerja setelah liburan tahun baru imlek.

Tabel 10.

Hasil Uji Perbedaan Abnormal Return Sektor yang Mengandung Unsur Logam dan Kayu pada $\mathbf{T}+\mathbf{1}$ di HKEX

\begin{tabular}{|l|l|l|l|}
\hline Mean & Mean & Mean & \\
LR & AR & differenc & \\
\hline 0.0254 & 0.02975 & - & $\mathrm{t}$ \\
6 & & 0.004292 & -0.574 \\
\hline
\end{tabular}

Berdasarkan hasil uji beda, tidak terdapat perbedaan abnormal return antara saham sektor yang direkomendasikan dan tidak direkomendasikan feng shui index.

Dengan begitu, adanya abnormal return pada sektor-sektor yang mengandung unsur logam pada hasil pengujian sebelumnya di HKEX tidak bisa digambarkan sebagai akibat adanya informasi feng shui index.

Hal ini menjadi indikator bahwa feng shui index tidak dipertimbangkan dalam pembuatan keputusan investasi di Hong Kong. Keberadaan feng shui memang 
masih cukup kuat di Hong Kong, tetapi setidaknya terdapat tiga alasan yang mampu menjelaskan mengapa pasar saham Hong Kong tidak terpengaruh informasi feng shui index. Pertama, arus modernisasi mulai menggeser kebudayaan Tiongkok. Inggris telah membentuk Hong Kong menjadi daerah industri yang modern dan maju, pasca pemindahan kekuasaan sekalipun. Seiring perkembangan jaman, kebudayaan Tiongkok mulai tergeser oleh modernisasi dan nilai-nilai barat. Paham feng shui kuno telah diubah secara bertahap karena tidak sesuai dengan budaya barat (Peplow dan Baker, 1931 dalam Smith, 1994). Rupanya, kepercayaan masyarakat Hong Kong terhadap feng shui mulai pudar sebagai akibat dari arus modernisasi. Emmons (1992) melakukan survei via telepon mengenai kepercayaan masyarakat Hong Kong terhadap feng shui. Dari 1980 responden, $65 \%$ di antaranya tidak mempercayai feng shui. Usia juga berhubungan positif dengan kepercayaan terhadap feng shui (Emmons, 1992). Etnis Tionghoa yang terpengaruh oleh takhayul adalah mereka yang berusia lanjut (Fredman, 1979 dalam Smith, 1994). Kedua, 33\% investasi di pasar Hong Kong berasal dari investor asing (Brown et al, 2002), sedangkan feng shui index lebih popular di kalangan investor domestik. Ketiga, penggunaan feng shui dalam dunia bisnis menjadi janggal menurut para praktisi bisnis. Praktik profesional dan bisnis lebih memerlukan rasionalitas dan keilmiahan (Emmons, 1992).

Namun, terdapat kemungkinan kedua yang menjelaskan mengapa tidak terdapat perbedaan abnormal return antara saham sektor yang direkomendasikan dan tidak di- 
rekomendasikan feng shui index. Hal ini

bisa disebabkan karena pada bulanbulan di awal tahun monyet api, yaitu pada bulan Februari hingga Maret, kinerja sektor yang mengandung unsur kayu masih dianggap bagus, tetapi mulai bulan Agustus hingga akhir tahun monyet api, kinerja sektor ini diprediksikan sangat buruk. Oleh karena itu, investor jangka pendek masih memepertimbangkan untuk memperoleh keuntungan dengan berinvestasi di saham-saham yang mengandung unsur kayu. Pernyataan ini sejalan dengan penelitian Fuller et al. (2009), bahwa Hong Kong cenderung memiliki mentalitas trading jangka pendek.
2. Taiwan

Tabel 11.

Ringkasan Hasil One Sample T-Test pada Sektor dengan Unsur Logam di TWSE

\begin{tabular}{|c|c|c|c|c|}
\hline Tanggal & & ri ke & Mean & t-stat \\
\hline 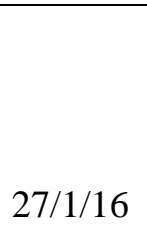 & 1 & T-7 & $\begin{array}{l}- \\
0.00511\end{array}$ & - \\
\hline $28 / 1 / 16$ & 0 & T-6 & 0.00262 & 1.106 \\
\hline $29 / 1 / 16$ & $\begin{array}{l}\mathrm{t} \\
+\end{array}$ & $\mathrm{T}-5$ & $\begin{array}{l}- \\
0.00586\end{array}$ & $2.404 * *$ \\
\hline $30 / 1 / 16$ & $\begin{array}{l}\mathrm{t} \\
+\end{array}$ & $\mathrm{T}-4$ & 0.00092 & 0.447 \\
\hline $1 / 2 / 16$ & $\begin{array}{l}\mathrm{t} \\
+\end{array}$ & $\mathrm{T}-3$ & - & -0.027 \\
\hline $2 / 2 / 16$ & $\begin{array}{l}\mathrm{t} \\
+ \\
4\end{array}$ & $\mathrm{~T}-2$ & 0.00063 & 0.393 \\
\hline $3 / 2 / 16$ & + & $\mathrm{T}-1$ & 0.00044 & 0.37 \\
\hline
\end{tabular}




\begin{tabular}{|l|l|l|l|l|}
\hline & 5 & & & \\
\hline & $\mathrm{t}$ & $\mathrm{T}+$ & & \\
& + & 1 & & \\
$15 / 2 / 16$ & 6 & & 0.01263 & $3.69 * * *$ \\
\hline
\end{tabular}

Keterangan:

$* *$ : signifikan $5 \%$

***: signifikan $1 \%$

Hasil pengujian one sample t-test pada tabel 11 menunjukkan Taiwan bereaksi pada $\mathrm{t}-1, \mathrm{t}+1$, dan $\mathrm{T}+1$, ditandai dengan terdapat abnormal return pada saham-saham sektor yang direkomendasikan feng shui index.

Tabel 12.

Hasil Uji Perbedaan Abnormal Return Sektor yang Mengandung Unsur Logam pada $t-1$ dan $t+1$ di TWSE

\begin{tabular}{|l|l|l|l|}
\hline Mean & Mean & Mean & \\
$\mathrm{AR}_{\mathrm{t}-1}$ & $\mathrm{AR}_{\mathrm{t}+1}$ & difference & $\mathrm{t}$ \\
\hline- & - & & \\
0.01085 & 0.00511 & -0.00586 & 0.233 \\
\hline
\end{tabular}

Berdasarkan hasil uji beda, tidak terdapat beda antara abnormal return saham sektor yang direkomendasikan feng shui index pada satu hari sebelum informasi feng shui index dirilis dan satu hari setelah informasi feng shui index dirilis.

Tabel 13.

Hasil Uji Perbedaan Abnormal Return Sektor yang Mengandung Unsur Logam pada $T-1$ dan $T+1$ di $T W S E$

\begin{tabular}{|l|l|l|l|}
\hline Mean & Mean & Mean & \\
$\mathrm{AR}_{\mathrm{T}-1}$ & $\mathrm{AR}_{\mathrm{T}+1}$ & differenc & \\
& & $\mathrm{e}$ & $\mathrm{t}$ \\
\hline 0.0004 & 0.0126 & - & -3.360 \\
\hline & 3 & 0.012182 & $* * *$ \\
\hline
\end{tabular}

Keterangan:

***: signifikan $1 \%$

Berdasarkan hasil uji beda, terdapat perbedaan antara abnormal return saham sektor yang direkomendasikan feng shui index pada satu hari kerja sebelum liburan tahun baru imlek dan satu hari kerja setelah liburan tahun baru imlek. 
Tabel 14.

Hasil Uji Perbedaan Abnormal Return Sektor yang Mengandung Unsur Logam dan Kayu pada T+1 di TWSE

\begin{tabular}{|l|l|l|l|}
\hline Mean & Mean & Mean & \\
Logam & AR & differen & \\
\hline 0.0126 & - & ce & $\mathrm{t}$ \\
3 & 0.00129 & 17 & $*$ \\
\hline
\end{tabular}

Keterangan:

**: signifikan $5 \%$

Berdasarkan hasil uji beda, terdapat perbedaan abnormal return antara saham sektor yang direkomendasikan dan tidak direkomendasikan feng shui index. Dengan begitu, adanya abnormal return pada sektor-sektor yang mengandung unsur logam pada hasil pengujian sebelumnya di TWSE dapat digambarkan sebagai akibat adanya informasi feng shui index.

Mayoritas masyarakat Taiwan menganut agama Buddha dan kepercayaan Taoisme yaitu $93 \%$ populasi (Central Intelligence Agency, 2016). Masyarakat etnis Tionghoa di
Tiongkok, Hong Kong, dan Taiwan adalah memiliki locus of control yang lebih external daripada Amerika Utara dan Eropa (Spector et al., 2002 dalam Kwok, 2010). Artinya, masyarakat etnis Tionghoa di Taiwan memiliki kepercayaan bahwa segala sesuatu terjadi sebagai akibat dari kekuatan di luar dirinya, seperti takdir, keberuntungan, maupun kesempatan. Karena karakteristik itu, masyarakat Taiwan masih mempercayai budayabudaya seperti feng shui. Selain itu, Proporsi investor asing di pasar saham Taiwan sebesar 7\% (Brown et al., 2002). Karena itu, informasi feng shui index menjadi relevan di pasar saham Taiwan yang didominasi investor domestik. 
3. Singapura

Tabel 15.

Ringkasan Hasil One Sample T-Test pada Sektor dengan Unsur Logam di SGX

\begin{tabular}{|c|c|c|c|c|}
\hline Tanggal & Ha & i ke & Mean & t-stat \\
\hline 27/1/16 & $\mathrm{t}-1$ & $\mathrm{~T}-8$ & $\begin{array}{l}- \\
0.00227\end{array}$ & -0.190 \\
\hline 28/1/16 & to & $\mathrm{T}-7$ & $\begin{array}{l}- \\
0.01197\end{array}$ & -1.471 \\
\hline 29/1/16 & $\begin{array}{l}\mathrm{t+} \\
1\end{array}$ & T-6 & 0.02270 & 1.122 \\
\hline $1 / 2 / 16$ & $\begin{array}{l}\mathrm{t+} \\
2\end{array}$ & $\mathrm{~T}-5$ & $\begin{array}{l}- \\
0.03282\end{array}$ & $\begin{array}{l}- \\
1.694 *\end{array}$ \\
\hline $2 / 2 / 16$ & $\begin{array}{l}t+ \\
3\end{array}$ & $\mathrm{~T}-4$ & $\begin{array}{l}- \\
0.01727\end{array}$ & -1.210 \\
\hline $3 / 2 / 16$ & $\begin{array}{l}t+ \\
4\end{array}$ & $\mathrm{~T}-3$ & $\begin{array}{l}- \\
0.02251\end{array}$ & -1.167 \\
\hline $4 / 2 / 16$ & $\begin{array}{l}\mathrm{t+} \\
5\end{array}$ & $\mathrm{~T}-2$ & $\begin{array}{l}- \\
0.00690\end{array}$ & -0.664 \\
\hline $5 / 2 / 16$ & $\begin{array}{l}\mathrm{t+} \\
6\end{array}$ & $\mathrm{~T}-1$ & 0.01807 & 0.984 \\
\hline $10 / 2 / 16$ & $\begin{array}{l}\mathrm{t+} \\
7\end{array}$ & $\begin{array}{l}\mathrm{T}+ \\
1\end{array}$ & $\begin{array}{l}- \\
0.03293\end{array}$ & -1.339 \\
\hline
\end{tabular}

Keterangan:

*: signifikan $10 \%$

Hasil pengujian one sample t-test pada tabel 15 menunjukkan Singapura tidak bereaksi sama sekali terhadap informasi feng shui index, ditandai dengan tidak terdapat abnormal return pada saham-saham sektor yang direkomendasikan feng shui index.

Tabel 16.

Hasil Uji Perbedaan Abnormal Return Sektor yang Mengandung Unsur Logam pada $t-1$ dan $\mathbf{t}+1$ di SGX

\begin{tabular}{|l|l|l|l|}
\hline Mean & Mean & Mean & \\
& $\mathrm{AR}_{\mathrm{t}-1}$ & differenc & \\
& & $\mathrm{e}$ & $\mathrm{t}$ \\
\hline- & 0.02270 & - & \\
& & 0.02497 & - \\
& & 7 & 1.062 \\
\hline
\end{tabular}

Berdasarkan hasil uji beda, tidak terdapat beda antara abnormal return saham sektor yang direkomendasikan feng shui index pada satu hari sebelum informasi feng shui index dirilis dan satu 
Efek Feng Shui Index ... (Karina Raesita, Putu Anom, dan Arif Herlambang)

hari setelah informasi feng shui index dirilis.

Tabel 17.

Hasil Uji Perbedaan Abnormal Return Sektor yang Mengandung Unsur Logam pada T-1 dan T+1 di SGX

\begin{tabular}{|l|l|l|l|}
\hline Mean & Mean & Mean & \\
$\mathrm{AR}_{\mathrm{T}-1}$ & $\mathrm{AR}_{\mathrm{T}+1}$ & difference & $\mathrm{t}$ \\
\hline 0.01807 & - & & 1.66 \\
& 0.03293 & 0.050997 & $1 *$ \\
\hline
\end{tabular}

Keterangan:

*: signifikan $10 \%$

Berdasarkan hasil uji beda, terdapat perbedaan antara abnormal return saham sektor yang direkomendasikan feng shui index pada satu hari kerja sebelum liburan tahun baru imlek dan satu hari kerja setelah liburan tahun baru imlek.

Tabel 18.

Hasil Uji Perbedaan Abnormal Return Sektor yang Mengandung Unsur Logam dan Kayu pada T+1 di SGX

\begin{tabular}{|l|l|l|l|}
\hline Mean & Mean & & \\
Logam & Kayu & difference & $\mathrm{t}$ \\
\hline-0.03293 & 0.01166 & & - \\
& & -0.044590 & 0.757 \\
\hline
\end{tabular}

Berdasarkan hasil uji beda, tidak terdapat perbedaan abnormal return antara saham sektor yang direkomendasikan dan tidak direkomendasikan feng shui index. Karena berdasarkan pengujian hipotesis sebelumnya juga tidak ditemukan abnormal return pada saham sektor yang direkomendasikan feng shui index, dan didukung dengan hasil pengujian hipotesis 8 yang mengatakan tidak terdapat perbedaan abnormal return kelompok saham sektor yang direkomendasikan feng shui index dan yang tidak direkomendasikan, informasi feng shui index tidak mempengaruhi keputusan investasi di pasar saham Singapura (SGX).

Berdasarkan hasil analisis pada pengujian hipotesis sebelumnya, informasi feng shui index tidak mempengaruhi pembuatan keputusan investor Singapura, baik pada tanggal- 
tanggal di sekitar rilisnya informasi tersebut ke publik maupun pada tanggal-tanggal di sekitar tahun baru imlek. Penduduk Singapura didominasi etnis Tionghoa, sebesar $74,1 \%$ populasi, dengan $57,4 \%$ di antaranya menganut agama Buddha dan kepercayaan Taoisme (Departement of Statistics, 2010). Masyarakat ini seharusnya mempercayai feng shui sebagai budaya yang menjadi nilai dan prinsip hidup. Faktanya, nilai-nilai kebudayaan dan kepercayaan tersebut mulai pudar di kalangan masyarakat Singapura, seperti yang ditemukan Lee dan Bishop (2001) dalam penelitiannya tentang Sistem Kepercayaan Klien Tionghoa tentang Permasalahan Psikologi di Singapura. Lee dan Bishop (2001) menemukan pudarnya kepercayaan orang Tionghoa di Singapura terhadap feng shui merupakan akibat dari modernisasi dan pergeseran budaya karena masuknya budaya barat ke Singapura. Hal ini sejalan dengan temuan Brown et al (2002). Di Singapura, tidak ditemukan bukti pengaruh budaya pada pasar saham meskipun $76 \%$ populasinya memiliki etnis Tionghoa, akibat pengaruh barat dan Muslim di pasar Singapura.

4. Indonesia

Tabel 19.

Ringkasan Hasil One Sample T-Test pada Sektor dengan Unsur Logam di BEI

\begin{tabular}{|c|c|c|c|c|}
\hline Tanggal & $\begin{array}{l}\mathrm{Ha} \\
\mathrm{ri} \\
\mathrm{ke}\end{array}$ & & Mean & t-stat \\
\hline $27 / 1 / 16$ & $\mathrm{t}-1$ & $\mathrm{~T}-8$ & -0.00713 & $\begin{array}{l}- \\
2.319 \\
* *\end{array}$ \\
\hline $28 / 1 / 16$ & to & T-7 & 0.00245 & 0.600 \\
\hline $29 / 1 / 16$ & $t+1$ & T-6 & 0.00958 & 1.542 \\
\hline $1 / 2 / 16$ & $\mathrm{t}+2$ & $\mathrm{~T}-5$ & -0.00066 & $\begin{array}{l}- \\
0.142\end{array}$ \\
\hline $2 / 2 / 16$ & $t+3$ & $\mathrm{~T}-4$ & 0.00360 & 0.961 \\
\hline $3 / 2 / 16$ & $\mathrm{t}+4$ & T-3 & 0.00323 & 0.429 \\
\hline
\end{tabular}


Efek Feng Shui Index ... (Karina Raesita, Putu Anom, dan Arif Herlambang)

\begin{tabular}{|l|l|l|l|l|}
\hline $4 / 2 / 16$ & $\mathrm{t}+5$ & & -0.0010 & 0.221 \\
\hline $5 / 2 / 16$ & $\mathrm{t}+6$ & & -0.00585 & 1.317 \\
\hline $9 / 2 / 16$ & $\mathrm{t}+7$ & $\mathrm{~T}+1$ & 0.00117 & 0.225 \\
\hline
\end{tabular}

Keterangan:

**: signifikan 5\%

Hasil pengujian one sample t-test pada tabel 19 menunjukkan Indonesia bereaksi hanya pada t-1 saja, sedangkan informasi feng shui index belum dirilis ke pasar. Hal ini menjadi indikasi bahwa reaksi pasar yang terjadi bukan disebabkan oleh informasi feng shui index, sehingga dapat disimpulkan bahwa pasar tidak bereaksi sama sekali terhadap informasi feng shui index, ditandai dengan tidak terdapat abnormal return pada saham-saham sektor yang direkomendasikan feng shui index.
Tabel 20.

Hasil Uji Perbedaan Abnormal Return Sektor yang Mengandung Unsur Logam pada $\mathbf{t}-\mathbf{1}$ dan $\mathbf{t}+\mathbf{1}$ di BEI

\begin{tabular}{|l|l|l|l|}
\hline Mean & Mean & Mean & \\
$\mathrm{AR}_{\mathrm{t}-1}$ & $\mathrm{AR}_{\mathrm{t}+1}$ & differenc & \\
\hline- & 0.0095 & - & $\mathrm{t}$ \\
0.00713 & 8 & 0.016702 & $2.410 * *$ \\
\hline
\end{tabular}

Keterangan:

$* *$ : signifikan $5 \%$

Berdasarkan hasil uji beda, terdapat beda antara abnormal return saham sektor yang direkomendasikan feng shui index pada satu hari sebelum informasi feng shui index dirilis dan satu hari setelah informasi feng shui index dirilis.

Tabel 21.

Hasil Uji Perbedaan Abnormal Return Sektor yang Mengandung Unsur Logam pada $\mathrm{T}-1$ dan $\mathrm{T}+\mathbf{1}$ di $\mathrm{BEI}$

\begin{tabular}{|l|l|l|l|}
\hline Mean & Mean & Mean & \\
$\mathrm{AR}_{\mathrm{T}-1}$ & $\mathrm{AR}_{\mathrm{T}+1}$ & differen & \\
& & ce & $\mathrm{t}$ \\
\hline- & 0.034413 & - & - \\
0.00585 & & 0.007021 & 1.028 \\
\hline
\end{tabular}


Berdasarkan hasil uji beda, tidak terdapat perbedaan antara abnormal return saham sektor yang direkomendasikan feng shui index pada satu hari kerja sebelum liburan tahun baru imlek dan satu hari kerja setelah liburan tahun baru imlek.

Tabel 22.

Hasil Uji Perbedaan Abnormal Return Sektor yang Mengandung Unsur Logam dan Kayu pada $\mathrm{T}+1$ di BEI

\begin{tabular}{|l|l|l|l|}
\hline Mean & Mean & Mean & \\
Logam & Kayu & ce & $\mathrm{t}$ \\
\hline 0.0011 & 0.01674 & - & \\
7 & & 0.01558 & -1.45 \\
\hline
\end{tabular}

Berdasarkan hasil uji beda, tidak terdapat perbedaan abnormal return antara saham sektor yang direkomendasikan dan tidak direkomendasikan feng shui index. Karena berdasarkan pengujian hipotesis sebelumnya juga tidak ditemukan abnormal return pada saham sektor yang direkomendasikan feng shui index, dan didukung dengan hasil pengujian hipotesis 8 yang mengatakan tidak terdapat perbedaan abnormal return kelompok saham sektor yang direkomendasikan feng shui index dan yang tidak direkomendasikan, informasi feng shui index tidak mempengaruhi keputusan investasi di pasar saham Indonesia (BEI).

Di Indonesia, $87.18 \%$ penduduk beragama Islam, dan hanya $0.77 \%$ yang beragama Buddha dan Konfusianisme (Badan Pusat Statistik, 2010). Dilihat dari sisi demografi, feng shui bukan merupakan budaya mayoritas penduduk. Hal ini yang mejelaskan mengapa informasi feng shui index tidak direspons oleh pasar, yang ditandai dengan tidak adanya abnormal return pada pengujian hipotesis di BEI.

Menjelang dan setelah liburan tahun baru imlek, juga tidak ditemukan 
abnormal return pada sektor-sektor yang mengandung unsur logam di Bursa Efek Indonesia. Hal ini sesuai dengan hasil penelitian Hidayat (2014) bahwa chinese new year effects tidak berpengaruh terhadap abnormal return saham di Bursa Efek Indonesia.

\section{Kesimpulan, Implikasi, dan}

\section{Keterbatasan}

Berdasarkan pengujian hipotesis, tidak ditemukan abnormal return pada saham sektor-sektor yang direkomendasikan feng shui index, yaitu sektor yang mengandung unsur logam (Jīn 金) pada pasar saham Indonesia dan pasar saham Singapura. Hal ini menunjukkan bahwa pasar saham Singapura dan Indonesia mengabaikan informasi feng shui index dalam pembuatan keputusan investasinya. Pasar saham Indonesia mengabaikan informasi feng shui index karena dilihat dari sisi demografi, feng shui bukan merupakan budaya mayoritas penduduk. Sementara itu, meskipun penduduk Singapura didominasi etnik Tionghoa sebesar 74,1\% populasi, dengan $57,4 \%$ di antaranya menganut agama Buddha dan kepercayaan Taoisme, pasar saham Singapura juga mengabaikan informasi feng shui index. Kepercayaan terhadap feng shui mulai pudar akibat modernisasi budaya.

Berdasarkan pengujian hipotesis, dapat disimpulkan bahwa informasi feng shui index menjadi relevan di pasar saham Taiwan karena ditemukan abnormal return saham sektor yang direkomendasikan feng shui index pada satu hari setelah informasi feng shui index dirilis ke publik $(t+1)$ dan pada hari kerja pertama di tahun monyet api (satu hari setelah liburan tahun baru imlek / T+1). Hal ini juga didukung dengan penerimaan hipotesis 8 yang menunjukkan ada perbedaan antara abnormal return saham 
yang direkomendasikan dan tidak direkomendasikan feng shui index pada $\mathrm{T}+1$. Mayoritas masyarakat Taiwan menganut agama Buddha dan kepercayaan Taoisme, serta memiliki external locus of control yang mempercayai segala sesuatu terjadi akibat kekuatan dari luar dirinya. Karena itu, feng shui index menjadi informasi yang relevan bagi keputusan investasi masyarakat Taiwan.

Di Hong Kong yang mayoritas penduduknya memiliki etnis Tionghoa, juga terdapat abnormal return sahamsaham sektor yang direkomendasikan feng shui index pada saat informasi feng shui index dirilis ke publik (t0), satu hari setelahnya $(t+1)$, satu hari sebelum liburan tahun baru imlek (T-1), dan satu hari setelah liburan tahun baru imlek $(\mathrm{T}+1)$. Namun, berdasarkan pengujian hipotesis 8, tidak ada perbedaan abnormal return pada saham-saham sektor yang direkomendasikan dan tidak direkomendasikan feng shui index, sehingga dapat disimpulkan bahwa informasi feng shui index tidak dipertimbangkan dalam pembuatan keputusan investasi di Hong Kong. Informasi feng shui index menjadi tidak relevan di Hong Kong karena arus modernisasi, proporsi investasi asing yang cukup besar, dan kejanggalan penggunaan feng shui dalam dunia bisnis menurut para praktisi bisnis.

Kemungkinan kedua yang
menjelaskan mengapa tidak terdapat
perbedaan abnormal return antara saham
sektor yang direkomendasikan dan tidak
direkomendasikan feng shui index yaitu
performa saham sektor yang mengandung
unsur kayu diprediksikan cukup baik di
awal tahun, dan diprediksikan sangat
buruk mulai bulan Agustus hingga akhir
tahun monyet api. Investor Hong Kong
yang sebagian besar memiliki mentalitas


trading jangka pendek masih mempertimbangkan untuk memperoleh keuntungan dengan berinvestasi di saham-saham yang mengandung unsur kayu pada awal periode monyet api.

Secara praktis, hasil penelitian ini dapat memberikan gambaran mengenai pengaruh feng shui index terhadap pasar saham Hong Kong, Taiwan, Singapura, dan Indonesia. Hasil penelitian ini juga dapat berguna bagi investor sebagai strategi trading saham di pasar saham Taiwan, khususnya di sekitar tahun baru imlek. Investor yang ingin bertransaksi di pasar saham Taiwan sebaiknya mengamati laporan feng shui index dari CLSA. Sementara itu, untuk investor yang ingin bertransaksi di pasar saham Indonesia, Singapura dan Hong Kong, tidak perlu berfokus pada feng shui dalam berinvestasi.

Keterbatasan penelitian ini adalah hanya menguji satu sektor yang direkomendasikan dan satu sektor yang tidak direkomendasikan feng shui index, sehingga tidak dapat memberi kesimpulan yang pasti di pasar saham Hong Kong. Peneliti berikutnya dapat menambah pasar saham yang di observasi seperti Tiongkok dan Korea Selatan, atau melakukan penelitian kausal berupa pengaruh feng shui index terhadap abnormal return pasar saham Taiwan. 


\section{DAFTAR PUSTAKA}

Brown, P., A. Chua, dan J. Mitchell, 2002, The Influence of Cultural Factors on Price Clustering: Evidence from Asia-Pacific Stock Markets, Pacifin-Basin Finance Journal, Vol 10:307-332

Emmons, Charles F., 1992, Hong Kong's Feng Shui: Popular Magic in a Modern Urban Setting, Journal of Popular Culture, Vol. 26(1): 39-49.

Fuller, D.B., dkk., 2009, Reinvigorating Hong Kong's Innovation System: An Overview of Hong Kong Innovation Project, Savantas Policy Institute.

Hidayat, I.C., 2014, Pengaruh Chinese New Year Effects Terhadap Abnormal Return Saham di Bursa Efek Indonesia, Skripsi, Universitas Katolik Soegijapranata Semarang.

Jogiyanto, 2000, Teori Portofolio dan Analisis Investasi, Edisi 2, BPFE Yogyakarta.

Kwok, L., 2010, Beliefs in Chinese Culture, Oxford Handbook of Chinese Psychology. p221-236.

Lee, B. dan Bishop, G.D., 2001, Chinese Client's Belief System About Psychological Problems in Singapore, Counselling Psychology Quarterly, Vol 14(3): 219-240.

Lee, R.P.L., 1991. Social Stress and Coping Behavior in Hong Kong, Hong Kong: Hong Kong Institute of Asia-Pacific.

Megginson, W.L., 1997, Corporate Finance Theory, Addison Weslye, Reading, Massachusetts.

MacKinlay, A.C., 1997. Event Studies in Economics and Finance. Journal of Economic Literature, Vol 35:13-39.

Peterson, P. P., 1989, Event Studies: A Review of Issues and Methodology, Quarterly Journal of Business and Economics, Vol 28(3):36-66

Smith, P.W., 1994, Identity, Land, Feng Shui and The Law in Traditional Hong Kong, Australian Journal of Law and Society, 213-240.

Yuan, Tian dan Rakesh Gupta, 2014, Chinese Lunar New Year Effect in Asian Stock Market, 1999-2012, The Quarterly Review Economics and Finance, Vol 54: 529-537. 